\title{
Food insecurity of HIV/AIDS patients at a unit of outpatient healthcare system in Brasilia, Federal District, Brazil
}

\author{
Ana Paula Sarmento Charão ${ }^{[1]}$, Meyre Hellen Ribeiro e Silva Batista ${ }^{[2]}$ and Luzitano Brandão Ferreira ${ }^{[1]}$
}

[1]. Faculdade de Ciências da Saúde, Centro Universitário de Brasília, Brasília, DF. [2]. Regional Asa Sul, Secretaria de Estado de Saúde do Distrito Federal, Brasília, DF.

\section{ABSTRACT}

Introduction: Food security remains to be one of the world's biggest problems and is found to be related to HIV/AIDS. The objective was to examine food insecurity in HIV/AIDS patients from Brasilia, Brazil. Methods: Short version of the Food Security Scale was applied to patients with HIV/AIDS. Results: A total of 103 patients participated (65 HIV+ and 38 with AIDS). Food insecurity was found in $33.8 \%$ of HIV+ patients and $36.8 \%$ of patients with AIDS. A relation between food insecurity and low educational and social levels was established. Conclusions: Food security should be an important component in HIV/AIDS treatment programs.

Keywords: Acquired immunodeficiency syndrome. Hunger. Public health nutrition.

Food security refers to the regular and permanent access of an individual to quality food in sufficient quantity, without compromising access to other essential needs. Its absence, food insecurity, has been recognized as one of the world population's biggest problems, either through lack of food and living conditions that prevent the adequate utilization of available food ${ }^{1}$. In Brazil, according to the National Survey by Household Sample (PNAD) on food security, more than $30 \%$ of households located in urban areas live in a situation of food insecurity ${ }^{2}$.

Diseases that decrease the ability to work are closely related to food insecurity, especially in developing countries, creating a vicious cycle that increases the vulnerability of individuals and worsens the severity of the disease. One of these serious diseases related to food insecurity is acquired immunodeficiency syndrome (AIDS) ${ }^{3}$.

According to the United Nations Program on HIV/AIDS (UNAIDS) ${ }^{4}$, the number of people living with HIV reached 33.4 million in 2008, and the number of AIDS-related deaths hit 3 million, so this disease remains a high healthcare priority. Among individuals with this disease, food insecurity is associated with decreased adherence to treatment, low cluster of differentiation (CD4) cell counts, increased viral load, incomplete suppression of HIV, an increase in opportunistic infections, and decreased survival rates of individuals ${ }^{5-6}$.

Despite the guidelines from international organizations to integrate HIV and nutrition programs, the effective implementation of such programs depends on database development and information management ${ }^{7}$. This requires knowing the situation of food insecurity in relation to this disease and the mechanisms that lead to it. In Brazil, there are few studies that seek to monitor the nutritional status of families ${ }^{8}$. Scarcer data are seen with regard to AIDS-related food insecurity. Thus, this study was undertaken to verify the presence of this condition in patients with this disease.

As a descriptive cross-sectional study, the survey involved HIV/AIDS patients undergoing outpatient treatment at the public

Address to: Dr. Luzitano Brandão Ferreira. FACS/UNICEUB. SEPN 707/907, Bloco 9, 70790-075 Brasília, DF, Brasil.

Phone: 5561 3966-1474

e-mail: luzitano-ferreira@uol.com.br

Received in 05/01/2011

Accepted in 07/02/2011 healthcare system in The Federal District (DF) of Brazil. The Federal District is the unit of the Brazilian federation with the highest human development index (HDI) (0.849) and per capita income in the country $(R \$ 6,473)$. The survey was conducted at a unit of outpatient healthcare system in the Federal District, specializing in the treatment of AIDS patients. It is located near the central city of Brasilia-DF, where the easy access of transportation (private and public) makes the unit a frequented place by residents of different regions of the Federal District. The number of patients was not predetermined, and all those who agreed to participate in the survey answered a questionnaire administered between September and November 2010.

The questionnaire was divided into three parts. First, there were questions aiming to characterize the participants with regard to age, gender, marital status, social and economic status (according to criteria of the Brazilian Studies and Research Association - ABEP), number of residents per household, and participants' work activity and educational level. Thereafter, questions checked clinical features such as CD4 cell count, viral load, and medication being used.

In the third stage of the study, the food insecurity check included questions (Portuguese version) ${ }^{8}$ from the short version of the Food Security Scale ${ }^{9}$. This assessment tool is suitable in the diagnosis of food security conditions and identification of populations at highest risk of insecurity and also for the observation of the impact of public policies on the population's access to adequate food.

The short form of the scale has six questions. Has the food ever run out in your home and you didn't have the money to buy more? Can you afford to buy your family balanced meals that include rice, beans, meat, salads, and fruit? Did you or someone else in your home have to ever cut the size of your meals or skip meals because there wasn't enough money for food? How often did this happen: almost every month, some months but not every month, or in only 1 or 2 months? Have you ever eaten less than you felt you should because there wasn't enough money for food? Have you ever been hungry but didn't eat because there wasn't enough money for food? These questions generate a score ranging from 0 to 6 . In four questions, each positive answer corresponds to a point, while in one of the questions the point was given to a negative answer, while in another, the score corresponds to the time of exposure when there was a decrease in 
the amount of food for lack of money. A period above or equal to three months was equivalent to 1 . Based on this questionnaire, patients with scores $0-1$ were defined as food secure (SEG), those whose scores were between 2-4 were categorized as insecure without hunger (INS), and patients who had scores 5-6 in their answers were insecure with hunger (IWH) 8 .

To check the differences between patients classified as SEG, INS, and IWH in relation to social-economic and clinic parameters, the Chi-square test or analysis of variance (ANOVA) were performed, whenever indicated. All participants signed an informed consent form, and this study was authorized by the Committee for Research Ethics of the Foundation for Health Science Education and Research (FEPECS) of the Government of the Federal District.

Of the 150 patients invited to participate, 103 participated in the survey. The food security and clinical conditions of 103 patients (65 HIV+ and 38 with AIDS), with an average of 42.6 years of age, were analyzed. Of the total HIV+ patients, $43(66.2 \%)$ were food secure $12(18.5 \%)$ were insecure without hunger, and 10 (15.4\%) were insecure with hunger. Of the AIDS patients, $24(63.2 \%)$ were food secure, 7 (18.4\%) were insecure without hunger, and 7 (18.4\%) were insecure with hunger (IWH) (Table 1).

Only $27.2 \%$ of patients had a higher educational level, while $43.7 \%$ had a secondary education degree, and $29.1 \%$ had primary education only. Individuals from lower social classes ( $D$ and $E$ ) represented over $73 \%$ of patients, while social classes B and C represented only $27 \%$. No individual from class $A$ took part in this study. Of the IWH individuals, $70.6 \%$ belonged to social class $\mathrm{E}$. In the same social class, $63.1 \%$ were INS individuals.

Most (63.3\%) patients were employed, while $18.4 \%$ were retired or had no regular job. Even retired patients and those with jobs had an overall prevalence of $23.3 \%$ of food insecurity, with or without hunger. There were three residents per household on average, but the range went from one to nine.

CD4 cell count above 500 cells $/ \mathrm{mm}^{3}$ was observed in most $(64.1 \%)$ of the patients, and only $35.9 \%$ were below this value. With respect to viral load, most (55.4\%) of the subjects had values above 500 copies $/ \mathrm{ml}$. The antiretroviral drugs commonly used by patients were: lamivudine (52.4\%), efavirenz (38.8\%), tenofovir $(30.1 \%)$, and zidovudine (19.4\%).

Analysis of patients classified as SEG, INS, and IWH showed differences that were not statistically significant $(p>0.05)$ for clinical condition, age, sex, occupation, marital status, viral load and medication. The analysis showed statistically significant differences $(p<0.05)$ between patients regarding educational level, social class and

\section{Ocupation}

TABLE 1 - Food security and insecurity data of HIV/AIDS patients.

\begin{tabular}{|c|c|c|c|c|c|c|c|c|c|}
\hline \multirow[b]{2}{*}{ Data of patients } & \multicolumn{2}{|c|}{$\begin{array}{c}\text { SEG } \\
(n=67)\end{array}$} & \multicolumn{2}{|c|}{$\begin{array}{c}\text { INS } \\
(n=19)\end{array}$} & \multicolumn{2}{|c|}{$\begin{array}{c}\text { IWH } \\
(n=17)\end{array}$} & \multicolumn{2}{|c|}{$\begin{array}{c}\text { Total } \\
(n=103)\end{array}$} & \multirow[b]{2}{*}{$\mathbf{p}$} \\
\hline & n & $\%$ & $\mathbf{n}$ & $\%$ & $\mathbf{n}$ & $\%$ & $\mathbf{n}$ & $\%$ & \\
\hline \multicolumn{10}{|l|}{ Clinical condition } \\
\hline HIV & 43 & 64.1 & 12 & 63.1 & 10 & 59.8 & 65 & 66.0 & 0.91 \\
\hline AIDS & 24 & 35.9 & 7 & 26.9 & 7 & 41.2 & 38 & 34.0 & \\
\hline Age (years) & \multicolumn{2}{|c|}{$42.9 \pm 11.3$} & \multicolumn{2}{|c|}{$44.0 \pm 8.5$} & \multicolumn{2}{|c|}{$41.1 \pm 6.8$} & \multicolumn{2}{|c|}{$42.6 \pm 10.1$} & 0.73 \\
\hline \multicolumn{10}{|l|}{ Sex } \\
\hline male & 50 & 74.6 & 12 & 63.1 & 14 & 82.3 & 76 & 73.7 & 0.41 \\
\hline female & 17 & 25.4 & 7 & 26.9 & 3 & 17.7 & 27 & 26.3 & \\
\hline \multicolumn{10}{|l|}{ Education } \\
\hline fundamental & 16 & 23.8 & 7 & 26.9 & 7 & 41.1 & 30 & 29.1 & \\
\hline medium & 26 & 38.9 & 10 & 52.6 & 9 & 52.9 & 45 & 43.7 & 0.03 \\
\hline superior & 25 & 37.3 & 2 & 10.5 & 1 & 6.0 & 28 & 27.2 & \\
\hline
\end{tabular}

\begin{tabular}{|c|c|c|c|c|c|c|c|c|c|}
\hline \multicolumn{10}{|c|}{ Social class* } \\
\hline B & 6 & 8.9 & - & - & 6 & 5.8 & & & \\
\hline C & 18 & 26.8 & 1 & 5.4 & 2 & 11.7 & 20 & 19.4 & 0.01 \\
\hline D & 23 & 34.3 & 6 & 31.5 & 3 & 17.6 & 34 & 33.0 & \\
\hline$E$ & 20 & 29.8 & 12 & 63.1 & 12 & 70.7 & 44 & 42.8 & \\
\hline
\end{tabular}

\begin{tabular}{|c|c|c|c|c|c|c|c|c|c|}
\hline regular job & 48 & 71.6 & 8 & 42.1 & 9 & 52.9 & 65 & 63.2 & \multirow{3}{*}{0.05} \\
\hline retired & 12 & 17.9 & 4 & 21.0 & 3 & 17.6 & 19 & 18.4 & \\
\hline no regular job & 7 & 10.5 & 7 & 26.9 & 5 & 39.5 & 19 & 18.4 & \\
\hline \multicolumn{10}{|l|}{ Marital status } \\
\hline married/stable union & 32 & 47.7 & 9 & 47.4 & 8 & 47.0 & 46 & 44.6 & \multirow[t]{2}{*}{0.99} \\
\hline single & 35 & 52.3 & 10 & 52.6 & 9 & 53.0 & 57 & 55.4 & \\
\hline \multicolumn{10}{|l|}{ TCD4 cells } \\
\hline$>500$ & 52 & 77.6 & 11 & 58.0 & 3 & 17.6 & 66 & 64.0 & \multirow{3}{*}{0.001} \\
\hline $500-20$ & 7 & 10.5 & 6 & 31.5 & 12 & 70.7 & 25 & 24.2 & \\
\hline$<200$ & 8 & 11.9 & 2 & 10.5 & 2 & 11.7 & 12 & 11.8 & \\
\hline \multicolumn{10}{|l|}{ Viral load } \\
\hline$<500$ & 32 & 47.7 & 9 & 47.5 & 5 & 29.4 & 46 & 44.6 & \multirow{3}{*}{0.61} \\
\hline $500-10,000$ & 22 & 32.8 & 6 & 31.5 & 6 & 35.3 & 34 & 33.0 & \\
\hline$>10,000$ & 13 & 19.5 & 4 & 21.0 & 6 & 35.3 & 23 & 22.4 & \\
\hline \multicolumn{10}{|l|}{ Medication } \\
\hline lamivudine & 33 & 49.2 & 11 & 58.0 & 8 & 47.0 & 54 & 52.4 & \multirow{4}{*}{0.61} \\
\hline efavirenz & 29 & 43.3 & 3 & 15.8 & 8 & 47.0 & 40 & 38.8 & \\
\hline tenofovir & 20 & 29.8 & 6 & 31.5 & 5 & 29.4 & 31 & 30.1 & \\
\hline zidovudine & 11 & 16.4 & 5 & 26.3 & 4 & 23.5 & 20 & 19.4 & \\
\hline
\end{tabular}

SEG: food security; INS: insecurity without hunger; IWH: insecurity with hunger. *Social class: according to criteria of the Brazilian Studies and Research Association (ABEP).

TCD4 cells count. As compared to the INS and IWH groups, patients in the food security group had higher education, ranked higher in the social class strata and had higher levels of TCD4 cells.

In 2004, according to the PNAD, the presence of food insecurity in the population of the Federal District was below $25 \%{ }^{2}$. In this study, in 2010, it was observed that $35 \%$ of HIV patients suffered from food insecurity, with or without hunger. This prevalence was three times higher than that recorded by Santos et al. ${ }^{8}$ in the urban population of the City of Pelotas, State of Rio Grande do Sul, Brasil (11\%), with an $\mathrm{HDI}(0.816)$ and per capita income ( $\mathrm{R} \$ 4,328.25)$ slightly lower than the ones in the Federal District, using the same assessment questionnaire. 
The differing situations of food insecurity in Brazilian regions are well established. In the Southern region, $75 \%$ of households have secured access to food, while in the North and Northeast, this occurred in approximately $50 \%$ of households ${ }^{2}$. It is a known fact that there is an increasing trend of AIDS cases among the lower-income populations. Thus, data obtained from food insecurity in this survey may be even lower than those found in other regions that have lower levels of human development and lower income per capita. Subsequent studies in different regions are needed to verify this condition.

The relationship among nutrition, financial situation and HIV infection, increased opportunistic infections, and progressive worsening of the disease is well known. The present study verified a higher number of individuals with food insecurity belonging to social class E. There was also increased food insecurity in patients with lower educational levels (elementary and secondary) compared with individuals with a higher social standing. The link among insecurity, educational level, and social and economic status was also noted in other studies ${ }^{8}$.

Zidovudine, efavirenz, tenefovir, and lamivudine (the drugs most commonly used by patients who participated in this study) have side effects that include anorexia, nausea, vomiting, and diarrhea. The worsening of side effects due to food insecurity leads to the deterioration of the patient's nutritional condition and decreases adherence to the treatment, leading to further progression of the disease ${ }^{10}$, increased resistance to antiretroviral therapy ${ }^{11}$, and increased costs of medical care to these patients ${ }^{12}$. Thus, food insecurity in HIV patients has deleterious effects not only to the patients but also to the healthcare system, by increasing its costs.

In Brazil, the annual cost of antiretroviral therapy was $R \$ 6,124$ per patient in 2005. In that same year, the spending on antiretrovirals in the budget of the HIV/AIDS Program reached $68.4 \%$, representing $2.7 \%$ of the total amount spent on health ${ }^{13}$. Considering that in the Federal District the monthly cost of an essential food basket is $R \$ 45.00$, and the annual spending on food per patient with food insecurity would be $R \$ 540.00$, which represents less than $10 \%$ of the spending on antiretroviral therapy. Government action has ensured that all HIV patients have access to antiretroviral medications. However, some characteristics seen in most patients with this disease, such as poverty, lower educational level, difficulty to get a job, prejudice, and even physical disability for work, may increase the risk of food insecurity.

The World Health Organization, UNAIDS, and the World Food Program have recommended the integration of food assistance with HIV/AIDS programs ${ }^{14}$. Nutritional intervention, leading to food security of patients receiving antiretroviral therapy, has increased medication adherence, fewer side effects, weight gain, and recovery of physical and work strength of the patients and their families ${ }^{15}$.

The serious consequences of food insecurity in relation to HIV/ AIDS reported in several studies and their prevalence observed in this study indicate that food security should be an important component of HIV/AIDS treatment programs in Brazil.

\section{ABSTRACT IN PORTUGUESE}

\section{Insegurança alimentar de pacientes com HIV/AIDS atendidos em uma unidade ambulatorial do sistema de saúde em Brasília, Distrito Federal, Brasil}

Introdução: Insegurança alimentar é um dos maiores problemas da população mundial e a AIDS está intimamente relacionada a esta condição. 0 objetivo foi verificar insegurança alimentar em pacientes adultos com HIV/AIDS em Brasília, Brasil. Métodos: Foi aplicada a versão curta da Escala de Segurança Alimentar a pacientes com HIV/AIDS. Resultados: Participaram 103 pacientes (65 HIV+ e 38 com AIDS). Insegurança alimentar foi verificada em 33,8\% dos pacientes HIV+ e $36,8 \%$ dos pacientes com AIDS. Foi observada relação entre insegurança alimentar e baixo nível educacional e social. Conclusões: Segurança alimentar deve ser parte importante nos programas de HIV/AIDS.

Palavras-chaves: Síndrome de imunodeficiência adquirida. Fome. Nutrição em saúde pública.

\section{CONFLICT OF INTEREST}

The authors declare that there is no conflict of interest.

\section{REFERENCES}

1. Ministério da Saúde. Estudo de caso Brasil: a integração das ações de alimentação e nutrição nos planos de desenvolvimento nacional para o alcance das metas do milênio no contexto do direito humano a alimentação adequada. Brasília: Ministério da Saúde; 2005.

2. Instituto Brasileiro de Geografia e Estatística. Pesquisa nacional por amostra de domicílios (PNAD) 2004: segurança alimentar. Rio de Janeiro: IBGE; 2006

3. Anema A, Vogenthaler N, Frongillo EA, Kadiyala S, Weiser SD. Food insecurity and HIV/AIDS: current knowledge, gaps, and research priorities. Curr HIV/AIDS Rep 2009; 6:224-231.

4. United Nations Program on HIV/AIDS. Report of the Global AIDS Epidemic [Internet]. [cited 2011 Nov 03]. Available from: http://www.unaids.org/ globalreport/Global_report.htm/.

5. Hardon AP, Akurut D, Comoro C, Ekezie C, Irunde HF, Gerrits T, et al. Hunger, waiting time and transport costs: time to confront challenges to ART adherence in Africa. AIDS Care 2007; 19: 658-665.

6. Weiser SD, Frongillo EA, Ragland K, Hogg RS, Riley ED, Bangsberg DR. Food insecurity is associated with incomplete HIV RNA suppression among homeless and marginally housed HIV-infected individuals in San Francisco. J Gen Intern Med 2009; 24:14-20.

7. Ivers LC, Cullen KA, Freedberg KA, Block S, Coates J, Webb P. HIV/AIDS, undernutrition, and food insecurity. Clin Infect Dis 2009; 49:1096-1102.

8. Santos JV, Gigante DP, Domingues MR. Prevalência de insegurança alimentar em Pelotas, Rio Grande do Sul, Brasil, e estado nutricional de indivíduos que vivem nessa condição. Cad Saude Publica 2010; 26:41-49.

9. Bickel GW, Nord M, Price C, Hamilton W, Cook J. Measuring food security in the United States. Guide to measuring household food security. Alexandria: United States Department of Agriculture; 2000.

10. Lima VD, Harrigan R, Murray M, Moore DM, Wood E, Hogg RS, et al. Differential impact of adherence on long-term treatment response among naive HIV-infected individuals. AIDS 2008; 12:2371-2380.

11. Volberding PA, Deeks SG. Antiretroviral therapy and management of HIV infection. Lancet 2010; 376:49-62.

12. Nachega JB, Leisegang $R$, Bishai $D$, Nguyen $H$, Hislop $M$, Cleary $S$, et al. Association of antiretroviral therapy adherence and health care costs. Ann Intern Med 2010; 152:18-25.

13. Grangeiro A, Teixeira L, Bastos FI, Teixeira P. Sustentabilidade da política de acesso a medicamentos anti-retrovirais no Brasil. Rev Saude Publica 2006; 40:60-69.

14. World Health Organization. Nutrient Requirements for People Living with HIV/ AIDS: Report of a Technical Consultation. Geneva, Switzerland: World Health Organization; 2003.

15. Byron E, Gillespie S, Nangami M. Integrating nutrition security with treatment of people living with HIV: lessons from Kenya. Food Nutr Bull 2008; 29:87-97. 